\title{
Ground penetrating radar surveys over an alluvial DNAPL site, Paducah Gaseous Diffusion Plant, Kentucky
}

[1994]

Oak Ridge National Lab., TN (United States)

Reproduced and Distributed by:

U.S. DEPARTMENT OF ENERGY

Office of Scientific and Technical Information

P.O. Box 62

Oak Ridge, TN 37831 


\section{DISCLAIMER}

This report was prepared as an account of work sponsored by an agency of the United States Government. Neither the United States Government nor any agency thereof, nor any of their employees, make any warranty, express or implied, or assumes any legal liability or responsibility for the accuracy, completeness, or usefulness of any information, apparatus, product, or process disclosed, or represents that its use would not infringe privately owned rights. Reference herein to any specific commercial product, process, or service by trade name, trademark, manufacturer, or otherwise does not necessarily constitute or imply its endorsement, recommendation, or favoring by the United States Government or any agency thereof. The views and opinions of authors expressed herein do not necessarily state or reflect those of the United States Government or any agency thereof. 


\section{DISCLAIMER}

Portions of this document may be illegible in electronic image products. Images are produced from the best available original document. 


\title{
GROUND PENETRATING RADAR SURVEYS OVER AN ALLUVIAL DNAPL SITE, PADUCAH GASEOUS DIFFUSION PLANT, KENTUCKY
}

\author{
P.J. Carpenter ${ }^{1,2}$, W. E. Doll 2 , and B.E. Phillips ${ }^{3}$ \\ 1 - Department of Geology, Northern Illinois University, DeKalb, IL 60115 \\ 2 - Environmental Sciences Division, Oak Ridge National Laboratory, \\ P.O. Box 2008, Oak Ridge, TN 37831-6317 \\ 3 - Paducah Gaseous Diffusion Plant, P.O. Box 1410, Paducah, KY 42001
}

\begin{abstract}
Ground penetrating radar (GPR) surveys were used to map shallow sands and gravels which are DNAPL migration pathways at the Paducah Gaseous Diffusion Plant in western Kentucky. The sands and gravels occur as paleochannel deposits, at depths of 17-25 ft, embedded in Pleistocene lacustrine clays. More than 30 GPR profiles were completed over the Drop Test Area (DTA) to map the top and base of the paleochannel deposits, and to assess their lateral continuity. A bistatic radar system was used with antenna frequencies of 25 and $50 \mathrm{MHz}$. An average velocity of $0.25 \mathrm{ft} / \mathrm{ns}$ for silty and clayey materials above the paleochannel deposits was established from radar walkaway tests, profiles over culverts of known depth, and comparison of radar sections with borings. In the south portion of the DTA, strong reflections corresponded to the water table at approximately 9-10 $\mathrm{ft}$, the top of the paleochannel deposits at approximately $18 \mathrm{ft}$, and to gravel horizons within these deposits. The base of these deposits was not visible on the radar sections. Depth estimates for the top of the paleochannel deposits (from $50 \mathrm{MHz}$ records) were accurate to within $2 \mathrm{ft}$ across the southern portion of the DTA. Continuity of these sands and gravels could not be assessed due to interference from air-wave reflections and lateral changes in signal penetration depth. However, the sands and gravels appear to extend across the entire southern portion of the DTA, at depths as shallow as $17 \mathrm{ft}$. Ringing, air-wave reflections and diffractions from powerlines, vehicles, well casings, and metal equipment severly degraded GPR profiles in the northern portion of the DTA; depths computed from reflection times (where visible) were accurate to within $4 \mathrm{ft}$ in this area. The paleochannel deposits are deeper to the north and northeast where DNAPL has apparently pooled (DNAPL was not directly imaged by the GPR, however). Existing hydrogeological models of the DTA will be revised with the newly defined extent and depth of these sands and gravels.
\end{abstract}

Note: The submitted manuscript has been authored by a contractor of the U.S. Government under contract No. DE-AC05-84OR21400. Accordingly, the U.S. Government retains a nonexclusive, royalty-free license to publish or reproduce the published form of this contribution, or allows others to do so, for U.S. Government purposes.

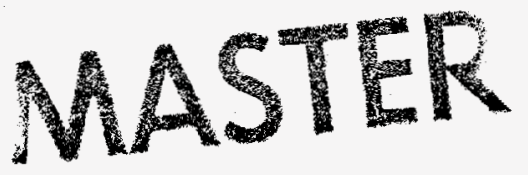




\title{
BACKGROUND
}

\author{
Objectives and Setting
}

In this study ground penetrating radar (GPR) was tested as a tool for mapping shallow discontinuous sand and gravel deposits which are pathways for migration of dense nonaqueous phase liquids (DNAPLs) at the Drop Test Area (DTA) of the Paducah Gaseous Diffusion Plant (PGDP) in western Kentucky (Figure 1). The PGDP is a uranium enrichment facility operated under contract for the U.S. Department of Energy. It lies at the northern tip of the Mississippi Embayment where Cretaceous-Quaternary sediments unconformably overlie Mississippian carbonates (Olive, 1980). Post-Eocene regional uplift, tilting, and erosion in this area produced a terraced landscape which was eventually buried by aggrading alluvial fan deposits of the Tennessee River. These alluvial materials were reworked and buried by late Pleistocene slackwater lake deposits and loess.

Prior to the GPR surveys, the northern DTA had been characterized by lithologic logs from three monitoring wells, two soil borings, and GeoProbe "push-rod" surveys at 36 locations (Davis, 1993). Only one soil boring was completed in the southern portion of the DTA. These investigations revealed a section consisting of $1-4 \mathrm{ft}$ of gravel fill, loose sand and loess overlying $13-17 \mathrm{ft}$ of silty clay. At $18-25 \mathrm{ft}$, discontinuous sand and gravel deposits are present, presumably representing channels and bars deposited during drops in the Wisconsinan slackwater lake level (Clausen et al., 1992). A thick section of sandy clay underlies these sands and gravels to a depth of approximately $40 \mathrm{ft}$. This clay separates the upper sands and gravels from the sands and gravels of the Regional Gravel Aquifer, which occur below $40 \mathrm{ft}$. Borings and monitoring wells in the DTA do not completely penetrate this aquifer, which is at least $30 \mathrm{ft}$ thick. Groundwater flow in the upper sands and gravels is primarily downward, whereas flow in the Regional Gravel Aquifer is primarily north toward the Ohio River (Clausen et al., 1992).

The DTA, in use between 1964 to 1979 , consisted of a concrete pad upon which uranium hexafluoride transport containers were dropped from various heights. A concrete tank $25 \mathrm{ft}$ west of the drop pad contained dry ice and trichloroethylene (TCE), into which the cylinders were immersed and chilled before they were dropped. An unknown amount of TCE leaked from this tank and contaminated shallow soils and groundwater. The tank was later removed. Groundwater TCE concentrations as high as $943 \mathrm{ppm}$, and soil concentrations as high as $388 \mathrm{ppm}$ (Davis, 1993) suggest the TCE exists as both a dissolved phase and a pooled DNAPL. Low concentrations of carbon tetrachloride, tetrachloroethane and other DNAPLs have also been detected in the DTA. The TCE contamination has migrated at least $50 \mathrm{ft}$ northeast of the former tank location and may contribute to a more extensive plume approximately $1200 \mathrm{ft}$ long, in the Regional Gravel Aquifer (Clausen et al., 1992). In the DTA, the DNAPL phase appears to occupy topographic lows in the sand and gravel deposits and the entire plume appears to be migrating downward along higher permeability sands and gravels (Davis, 1993). Remediation technology demonstrations for the shallow sediments at the DTA are planned for early 1994 . The 


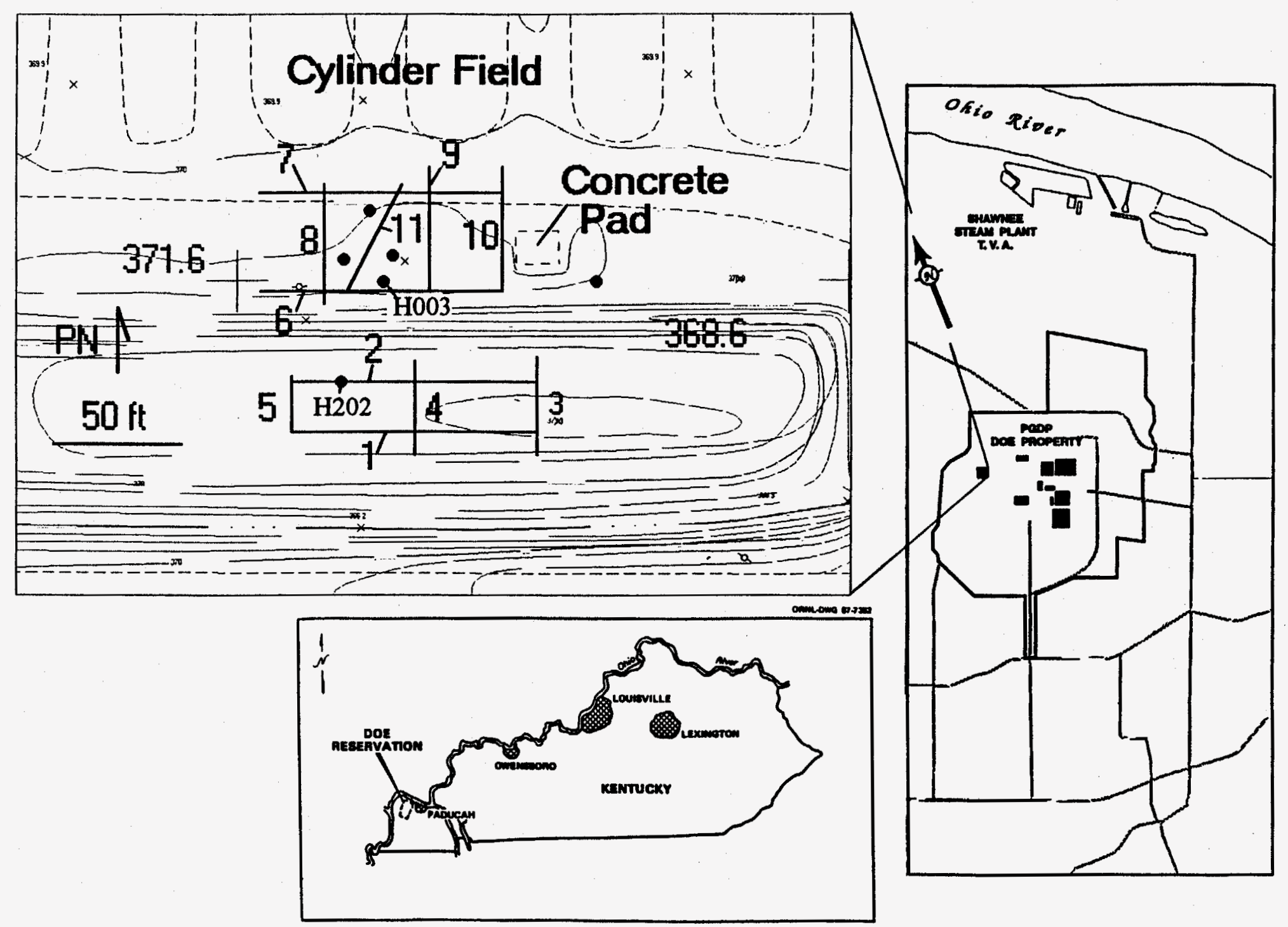

Figure 1 Location of the Drop Test Area. GPR profile lines are numbered, monitoring wells and older soil borings are shown as dots, $0.2 \mathrm{ft}$ elevation contours are also shown. $\mathrm{PN}$ refers to plant north. 
GPR investigations were intended to supplement site characterization prior to these remedial demonstrations. High-frequency seismic reflection data have also recently been acquired to support the GPR investigations.

\section{Previous Geophysical Surveys}

CH2M Hill (1991) conducted magnetic and electromagnetic surveys over the DTA and identified the probable location of the TCE and dry ice tank from metal debris in the pit fill material. HRGI (1993) performed vertical electrical soundings, electromagnetic and GPR profiles along two parallel east-west lines in the southern portion of the DTA. Nine Schlumberger soundings were inverted for 3- and 4-layer models consisting of a 75-165 ohm-m upper layer (2-7 ft thick), interpreted as sandy clay and fill, a lower resistivity middle layer (33-55 ohm-m) extending to approximately $30 \mathrm{ft}$, interpreted as clay with discontinuous sand and gravel units, and a high resistivity half-space (90-210 ohm-m), interpreted as sands and gravels of the Regional Gravel Aquifer. The soundings were not able to delineate the presence of the shallow sands and gravels encountered in nearby borings at $18-25 \mathrm{ft}$, although frequency-domain electromagnetic profiles did reveal terrain conductivity decreases of $2-3 \mathrm{mS} / \mathrm{m}$ over presumed sand/gravel deposits in the upper $35 \mathrm{ft}$. The average ground conductivity in the upper $25 \mathrm{ft}$ was $13 \mathrm{mS} / \mathrm{m}$. Two GPR profiles with a $120 \mathrm{MHz}$ antenna showed reflectors such as culverts and shallow stratigraphy to a depth of $5.5 \mathrm{ft}$. The radar velocity was estimated to be $0.22 \mathrm{ft} / \mathrm{ns}$ for the upper $5.5 \mathrm{ft}$.

\section{DATA COLLECTION}

The DTA is bisected by a drainage ditch which was difficult to profile across with the radar equipment; radar profile lines were thus clustered north and south of the ditch. Five profile lines were located over the southern area and six over the northern area (the site of the former tank and DNAPL plume). GPR profiles were made using the pulseEKKO IV radar system with 25 and 50 $\mathrm{MHz}$ antennas, and 3 and $5 \mathrm{ft}$ antenna separations, respectively. These separations were based on walkaway tests, in which radar traces were recorded at different antenna separations, the antenna radiation pattern, the target depth and logistical considerations. Once the profiling separation was selected, the antennas were moved along the survey lines in a perpendicular-broadside configuration with stations at $1 \mathrm{ft}$ intervals. Each station was at the transmitter-receiver midpoint. A radar trace representing 128 stacked radar pulses was collected at each station, processed, and displayed with other traces as a radar time section.

\section{PROCESSING AND INTERPRETATION}

Prior to interpretation all GPR traces were dewowed (the slowly decaying transient following the transmitted pulse was removed), low-pass filtered, and time-shifted to align the first breaks across the sections. Either automatic gain control (AGC) or spreading and exponential compensation (SEC) was used to boost amplitudes of later-arriving reflections. AGC windows were one source pulsewidth in duration with maximum gains of 100 or 200 . A velocity of 0.25 
$\mathrm{f} / \mathrm{ns}$, an attenuation factor of $3 \mathrm{~dB} / \mathrm{m}$ and a maximum gain of 200 was used for SEC. AGC was not used to display sections when lateral reflector continuity was evaluated since relative trace-totrace amplitude information is lost with AGC. The only other processing was to subtract the average trace from selected radar sections to reveal dipping events or to reduce ringing.

\section{Sources of Interference}

Powerlines, wells, vehicles, and metal objects at the surface produced significant interference in the radar sections. Air-wave reflections and diffractions from powerlines, powerpoles, well casings, vehicles and other metal or concrete objects on the surface were the most common problem and may be identified by the gentle trajectory of their diffraction hyperbolas. In many cases, however, only one branch of the hyperbola is present and care must be taken not to identify it as a dipping reflector. Tighter hyperbolas representing diffractions from culverts and subsurface well casings are also present on some of the profiles, as is ringing.

\section{Velocity and Depth Estimates}

Reflection times were picked at the first strong positive or negative peak of a reflection. The difference between this time and the arrival time of the air-wave pulse was used to compute the approximate depth of the reflection. The peak of the waveform was used since inflection points or first breaks of reflections were often obscured by interference.

The velocity of unsaturated near-surface materials was estimated from times of reflections over culverts of known depth, from the hyperbolic trajectory of diffractions over these same culverts, and through walkaway tests in which the ground-wave velocity was measured. These experiments provided a range of velocities from $0.2-0.35 \mathrm{ft} / \mathrm{ns}$. The velocity to materials beneath the water table was determined through a calibration of reflections believed to be from the shallow sand and gravel unit encountered in boring $\mathrm{H} 202$. The average velocity for these reflections was $0.25 \mathrm{ft} / \mathrm{ns}$, which reflects travel through both saturated and unsaturated materials. As this value also falls in the range of unsaturated velocity estimates, it was adopted for general use in depth determinations. It corresponds to a relative dielectric permittivity of 16 .

Depths were computed using $z=\left\{[t v]^{2}-x^{2}\right\}^{1 / 2} / 2$, where $z$ is the depth, $t$ the 2-way travel time, $v$ the average velocity to the reflector, and $x$ the separation distance between the transmitting and receiving antennas. Lateral and vertical variations in dielectric permittivity are present along the radar profiles and will add error to depth determinations. The width of the reflected pulse, interfering reflections and diffractions will also limit depth accuracy. Probably the best estimate of depth accuracy is to compare depths computed from radar sections with soil borings, or to compare reflector depths computed along intersecting or adjacent radar lines. 


\section{Radar Section Interpretation}

\section{SOUTH PROFILES}

\section{Shallow Reflections Above the Paleochannel Deposits}

Line 2 (Figures 2 and 3 ) intersects soil boring $\mathrm{H} 202$ at $80.5 \mathrm{ft}$. This profile also was relatively free from surface reflections, diffractions, ringing and noise caused by instrumental problems. As a matter of convenience, traces on all sections presented here are shaded to the right, although significant reflections may be either positive or negative, depending on the permittivity contrast at the reflecting surface.

In both the 25- and $50 \mathrm{MHz}$ profiles, the first positive event on the radar sections is the air-wave traveling directly from the transmitter to the receiver. The transmitted pulse approximates a minimum phase wavelet, although dewowing introduces a precursor to the direct air wave, which is shown as a trough arriving before time zero (SSI, 1993). The next shaded positive peak represents the direct ground wave interfering with the last part of the air-wave. A third strong reflector is present on the $50 \mathrm{MHz}$ profiles with a 2-way travel time of approximately $60 \mathrm{~ns}$, which translates to an approximate depth of $6 \mathrm{ft}$ (Figure 3). This reflector may represent the base of the loess and top of the silty clay lacustrine facies. This reflector is delayed by about $20 \mathrm{~ns}$ between stations 58 and 83 . A gravel pad visible at the surface at this location suggests an excavation in this area, although no indication of this is provided in boring $\log \mathrm{H} 202$. It is unlikely this delay is due to a lower velocity in the gravel fill since velocities over $0.3 \mathrm{ft} / \mathrm{ns}$ were measured for unsaturated gravel fill overlying culverts east of the DTA. Also, travel times of later reflections (such as the water table) do not appear to be delayed by this feature. A strong negative reflection at $90 \mathrm{~ns}(9.6 \mathrm{ft})$ is interpreted as the top of the water table (Figure 3). The actual water table depth in the southern part of the DTA at the time of the surveys was measured at $9 \mathrm{ft}$.

Critically refracted air-waves from reflectors were not identified on these radar sections. Critical angles of 14 to 20 degrees were computed for the soil-air interface and, at the small antenna separations used in this study, such waves would arrive at most a few ns before, or after, the primary reflection. However, such waves could emerge and reflect off objects on the surface, arriving as air-wave reflections at later times.

\section{Reflections from Paleochannel Deposits}

Comparison of the $25 \mathrm{MHz}$ section along Line 2 with boring H202 (Figure 2) suggests some of the strong reflectors between 150 and $250 \mathrm{~ns}$ represent the target sands and gravels. The undulatory and somewhat discontinuous character of these reflectors could be real, or may be due to interference with gently-dipping air-wave reflections. The top of the sequence is marked by a strong positive reflection at about $150 \mathrm{~ns}$ which is probably the top of the sand unit at a depth of $18 \mathrm{ft}$. Another strong positive reflection appears at about $170 \mathrm{~ns}$, which may represent the top of 


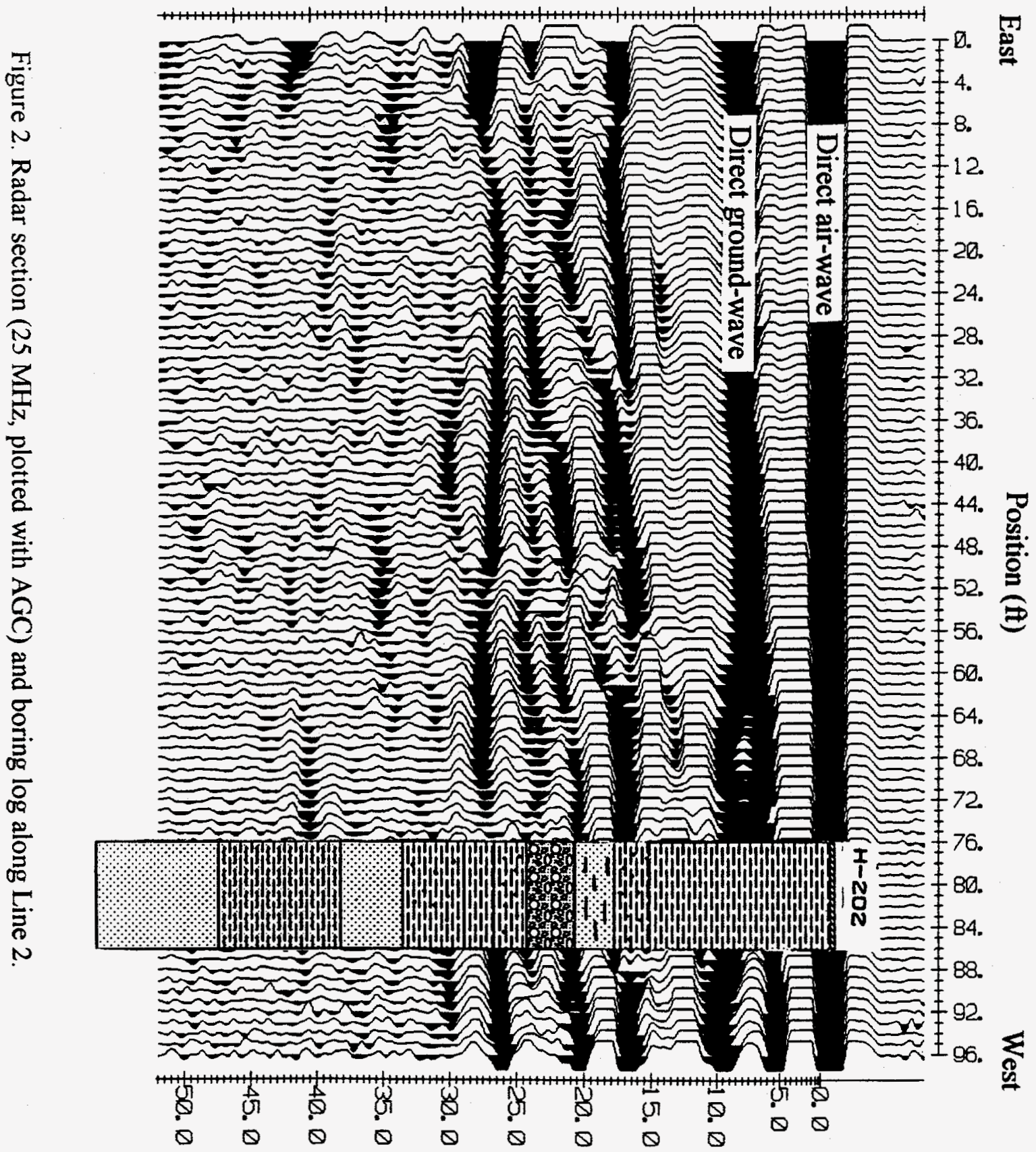

Depth ( $F t$ ) $v=0.250 \mathrm{Ft} / \mathrm{ns}$ 
su/zt $\theta \operatorname{\theta ec} \theta=1$ (7t) 47d

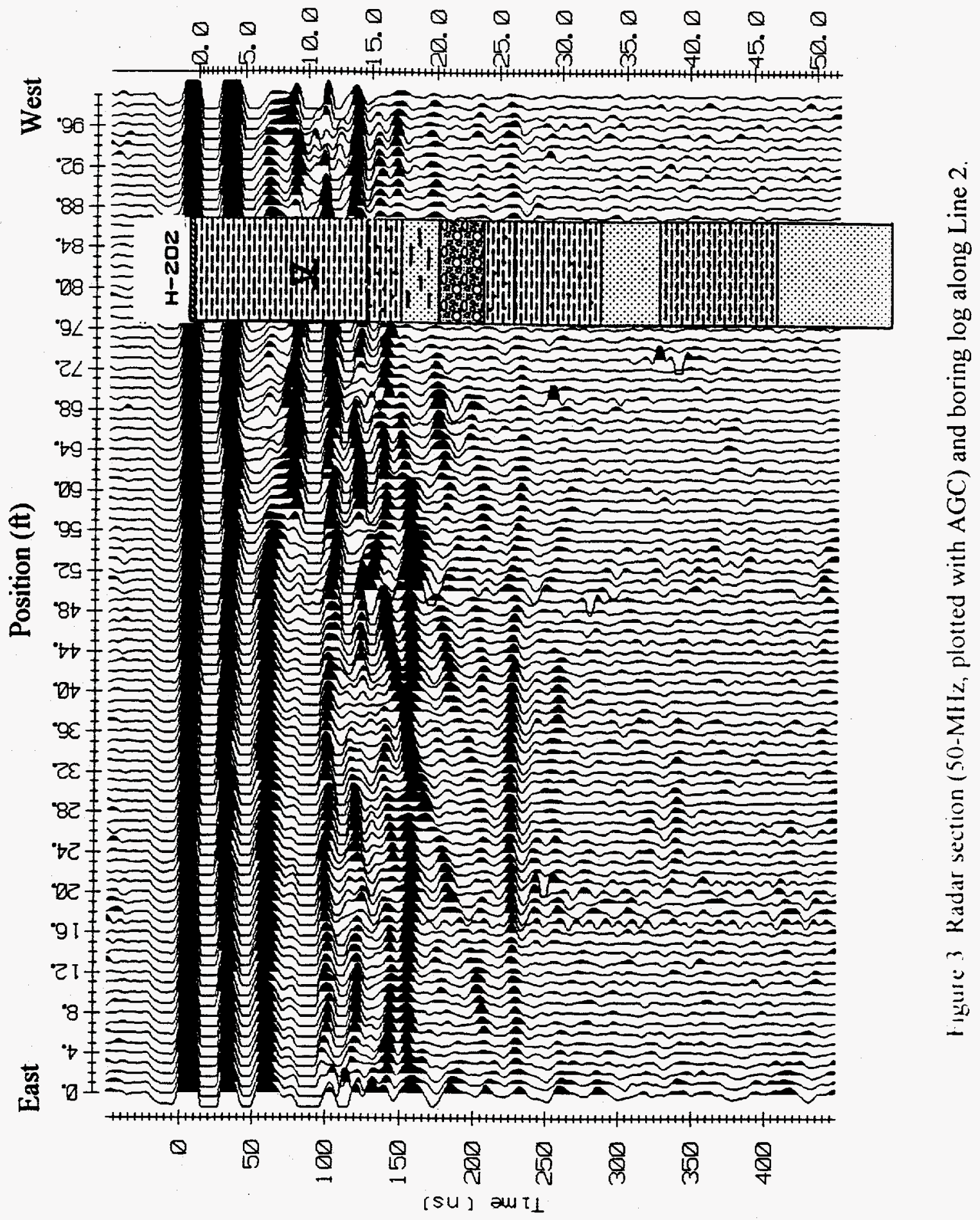


the gravel facies. If this identification is correct, the gravel facies appear to thicken westward. The apparent disruption between stations 34 and 58 represents interference with a gently-dipping airwave reflection from an overhead power line to the northwest. Actually, this reflector is probably continuous across the entire section, suggesting that the sand and gravel facies in this area extend over 100 feet along an east-west direction. Discontinuities, if present, must be significantly smaller than the $9 \mathrm{ft}$ Fresnel zone radius at this frequency (Yilmaz, 1987). The strong positive reflection at about $230 \mathrm{~ns}$ is enigmatic; it appears to be too deep, and is of the wrong polarity, to represent the base of the gravel overlying sandy clay. The strength and persistence of this reflection suggests it is real. It may represent a lateral facies change to sand or gravel (from sandy clay) east of $\mathrm{H} 202$.

The same reflector sequence is visible on the $50 \mathrm{MHz}$ section in more detail (Figure 3). This profile also shows discontinuous reflections between the water table reflection at $90 \mathrm{~ns}$ and the top of the sand and gravel unit at $160 \mathrm{~ns}$. The $160 \mathrm{~ns}$ reflector becomes very weak and disappears beneath the disrupted region west of station 58 . The $230 \mathrm{~ns}$ reflection persists through this segment; although at reduced amplitude. It "brightens up" to the east, again suggesting a lateral facies change in the unit underlying the gravel. The gently dipping powerline diffraction, as well as discontinuities in reflections around station 50 (the console box and a vehicle were moved) are clearly visible in Figure 3 . These dipping events may be further enhanced by subtracting the average trace from the section. The $50 \mathrm{MHz}$ sections thus allow air-wave reflections to be more readily identified and provides better resolution of shallow reflectors and structures at the expense of depth penetration in disrupted areas containing gravel. The same package of reflections between 150 and 250 ns are visible on profiles $1,3,4$, and 5 . The top of the gravelly sand is a particularly prominent reflector on Line 3 at 155 ns (Figure 4).

\section{NORTH PROFILES}

The northern GPR lines (6-11) were located among the cluster of wells marking the site of the DNAPL plume. All of these lines are plagued by strong air-wave reflections from powerlines, powerpoles, well casings, concrete pillars, metal equipment, cables, 55-gallon drums, vehicles, and steel culverts (Figures 5 and 6 ). These sections are also degraded by ringing, with a radar pulse arriving every 40-50 ns. The ringing interferes with reflections and makes trace-to-trace amplitude comparisons impossible. This ringing also totally masks reflections on most $25 \mathrm{MHz}$ records. Although some ringing occurs in the southern GPR profiles, it is much stronger in the northern area. This ringing could be due to air-wave energy multiply reflected between the antennas and some relatively distant surface object, such as the uranium hexafluoride cylinders. Line 9 (Figure 5) shows this ringing (in part) commencing earlier as the cylinder field is approached. A less likely possibility, given the high attenuation, is that ringing originates from energy trapped within the 3-4 ft of gravel fill at the surface (Davis, 1993) or represents energy trapped between the surface and the water table (which is about $6.5 \mathrm{ft}$ deep in the northern area).

Despite these problems, some useful information was obtained from $50 \mathrm{MHz}$ radar lines deployed in the northern area. SEC gain was used to display these sections since AGC greatly enhanced the ringing and air-wave reflections. Events between 140 and $270 \mathrm{~ns}$ are present near the east end of 

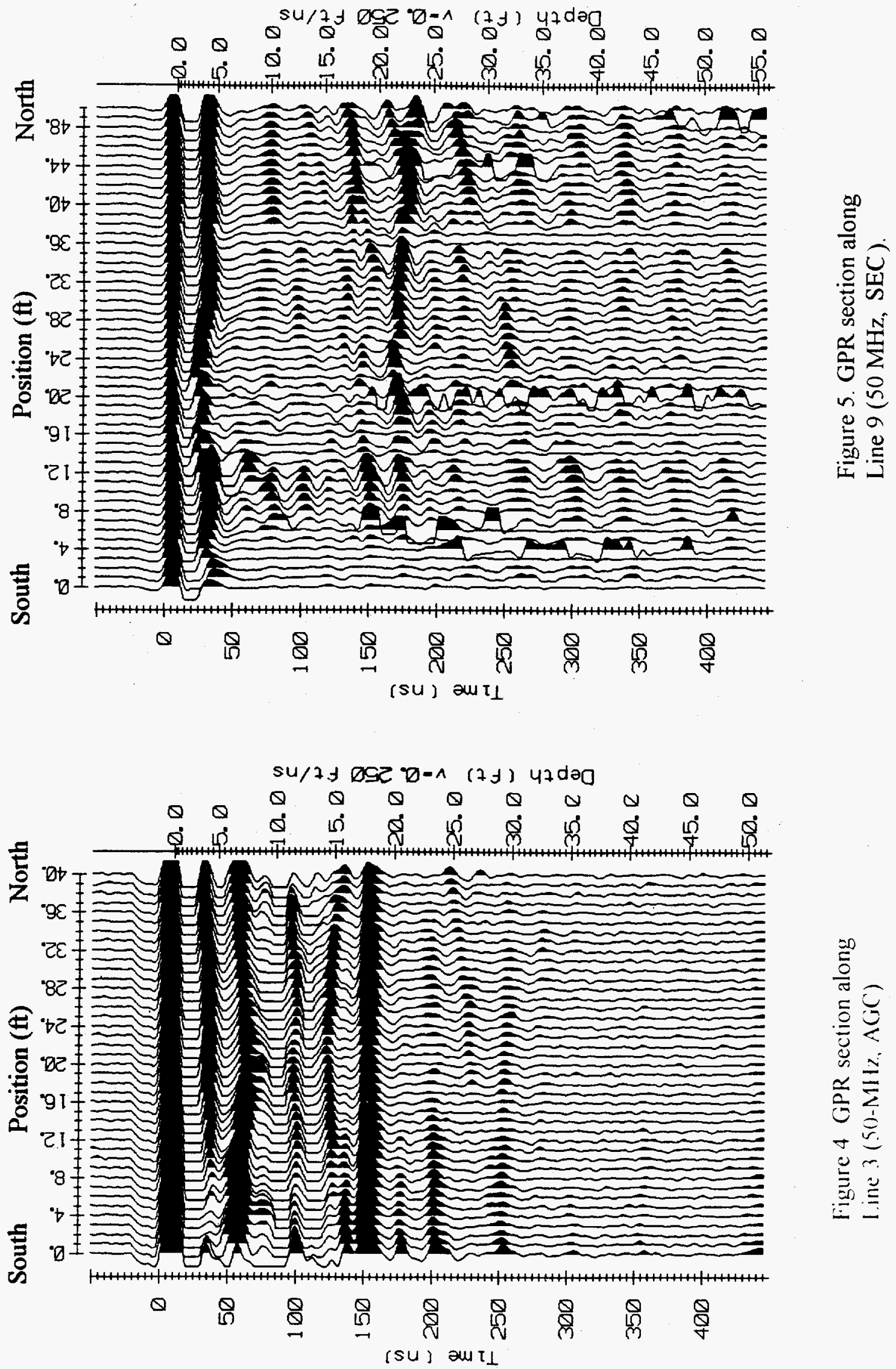


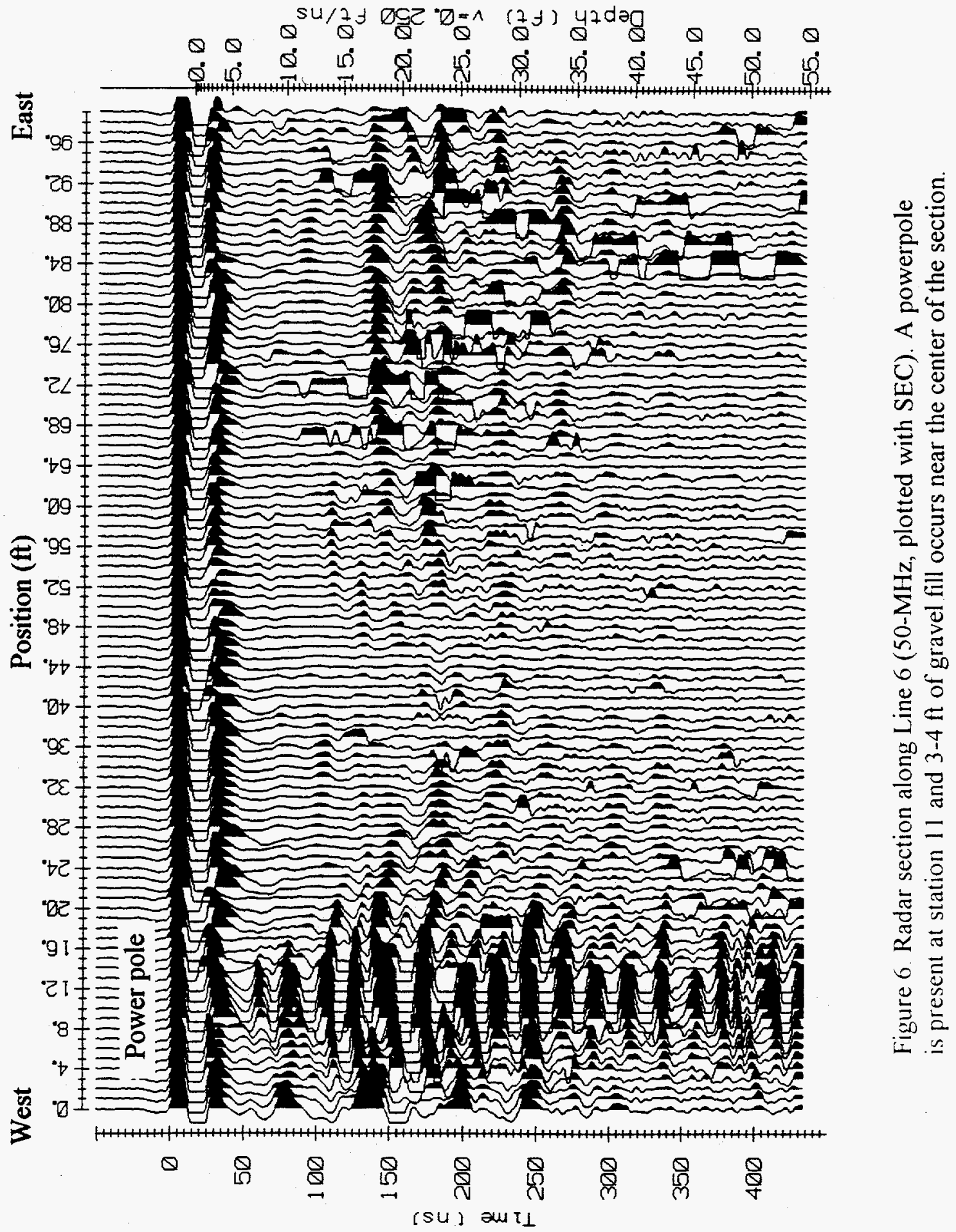


Line 6 (Figure 6) and may correspond to reflections from the sand and gravel facies. Soil boring $\mathrm{H} 003$, located near the center of this line, encountered a sand at a depth of about $19 \mathrm{ft}$, which agrees reasonably well with the $140 \mathrm{~ns}$ reflection on the radar profile. This boring also indicates $3-$ $4 \mathrm{ft}$ of sand and gravel fill near the center of Line 6 which corresponds to an area where the paleochannel reflections are weak or absent. Line 9 also shows strong positive reflections at 160 175 ns (Figure 5) through severe noise. These reflections are interpreted as the top of the sand and gravel deposits. No reflections corresponding to the base of the deposits, or gravel layers within these gravelly sands, were observed on any profile in the northern DTA.

\section{Comparisons Between GPR and Borehole Data}

Figure 7 depicts the depth to the top of the shallow sand and gravel unit from soil borings, monitoring wells and the GPR profiles. The estimated depth to the top of the sand and gravel unit from the $50 \mathrm{MHz}$ GPR data is superimposed on the GPR profile lines at various points. Although the $25 \mathrm{MHz}$ sections also showed many of these reflectors (sometimes with larger amplitudes), the $50 \mathrm{MHz}$ sections provided better depth resolution, were less affected by ringing, and allowed interfering air-wave reflections to be clearly identified. Overall, too few reflections were present to define the thickness or extent of gravelly subunits, or the base of the sand and gravel unit, from the GPR data. There was little discernible real dip in this unit on the sections. As the sand and gravel reflector did not appear on segments of many GPR lines, particularly in the northern portion of the study area, Figure 7 shows only those segments of the lines which exhibited the sand and gravel reflector on either the 25 or $50 \mathrm{MHz}$ sections.

The accuracy of the GPR method in delineating the top of the sand and gravel unit may be assessed through a comparison of the boring and well data with the GPR derived depths in Figure 7. Line 2 was calibrated to the boring data, so no variations are expected. Lines $1,3,4$ and 5 , however, all show the top of the sand and gravel unit within $1 \mathrm{ft}$ of the level indicated in boring H202, along Line 2. The sand and gravel unit appears to extend throughout the entire southern area. Lines 1 and 3 exhibit a $2 \mathrm{ft}$ variation in the depth of this unit at their intersection.

Estimates of the sand and gravel reflector depth in the northern portion of the DTA exhibit larger variations. In some cases, GPR-derived depths appear too shallow (Lines 6,7,11) and in one case (Line 9) slightly deeper than borings record. Line 9, however, does cross a deeper portion of the paleochannel, which trends to the northeast (Davis, 1993).

\section{HYDROGEOLOGY AND GPR RESULTS}

The purpose of the GPR surveys was to delineate shallow sands and gravels at the DTA which are potential DNAPL migration pathways. Surveys made in the northern part of the DTA, over the existing DNAPL plume, were hampered by ringing and noise from numerous air-wave reflections. However, some sands and gravels identified on the radar records (Line 9) confirm the presence of localized deeper paleochannel deposits where the DNAPLs have migrated. No reflections were identified on the radar records from the actual DNAPLs. 


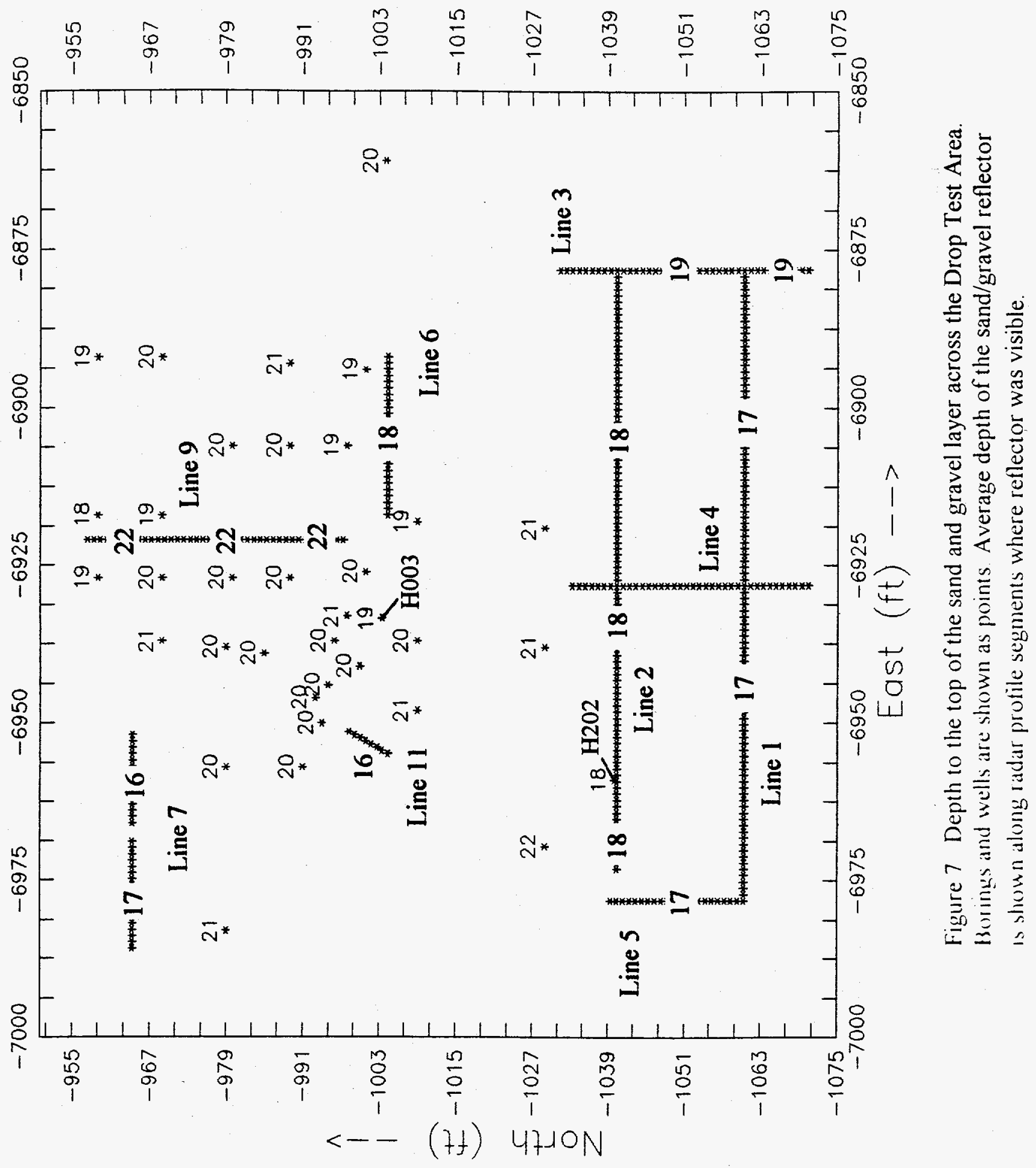


Radar records obtained over the southern portion of the DTA reveal sands and gravels across the entire southern area at depths as shallow as $17 \mathrm{ft}$. These deposits are 2-3 ft shallower to the south than they are to the north, and the southern area is also about 1-2 $\mathrm{ft}$ higher in elevation. A lowpermeability zone in these sands and gravels is also believed to exist between the northern and southern areas (Davis, 1993). It is thus highly unlikely DNAPLs will migrate southward from the DTA. In fact, no significant contamination has been detected in shallow soils or groundwater in the southern DTA (Davis, 1993).

\section{SUMMARY}

This study evaluated ground penetrating radar as a tool for mapping the depth, structure and continuity of shallow sands and gravels embedded in clay-rich sediments beneath the Drop Test Area of the Paducah Gaseous Diffusion Plant in western Kentucky. Walkaway tests, GPR profiles over culverts, and comparisons between GPR profiles and borings established an average radar wave velocity of $0.25 \mathrm{ft} / \mathrm{ns}$ for material within the upper $25 \mathrm{ft}$. Eleven GPR profiles over the Drop Test Area produced the following results:

(1) In the southern portion of the area, sources of noise were limited to air-wave reflections off a powerline, a vehicle, and occasional instrumental effects. Both 25 and $50 \mathrm{MHz}$ antennas imaged reflections from the top of the shallow gravelly sand as well as a gravel subunit. This gravelly sand appears to extend beneath the entire southern area. The $50 \mathrm{MHz}$ radar sections also clearly showed air-wave diffractions from powerlines, shallow reflectors such as the water table, and an excavated area. The depth to the top of the sand and gravel unit, computed from the $50 \mathrm{MHz}$ radar data, had an uncertainty of about $2 \mathrm{ft}$, when compared with depth estimates from borings and between intersecting radar lines.

(2) Radar sections from the northern part of the area (the location of the former tank and present DNAPL plume) were severly degraded by numerous air-wave reflections, diffractions and strong ringing. This ringing rendered $25 \mathrm{MHz}$ sections useless. Reflections from the top of the sand and gravel unit were generally only visible along short segments of the $50 \mathrm{MHz}$ profiles. Where visible, reflections were used to estimate the depth to the top of the sand and gravel unit within 4 $\mathrm{ft}$ of its depth indicated by borings and other data.

(3) The degree of continuity of the sands and gravels could not be assessed in such a noisy environment. Reflection continuity was disrupted by surface and shallow subsurface diffractions, near-surface lithology changes and interference from multiple reflections. The radar sections, however, do appear to show relatively continuous sand and gravel layers in the southern Drop Test Area, rather than separate lenses.

(4) Although no direct detection of DNAPL was made from radar surveys in the Drop Test Area, the GPR surveys provided useful information on the extent and depth of the sands and gravels 
which are DNAPL migration pathways. These results will be used to update hydrogeological models prior to remediation of the Drop Test Area. They also provide impetus for PGDP to use radar at an earlier stage in subsequent projects -- before objects of interference are introduced.

\section{ACKNOWLEDGEMENTS}

We wish to thank Ken Davis, Ron Kaufmann and Eric Morti for assistance in collecting the radar data, and to Les Beard and Jon Nyquist for reviewing this manuscript and supplying helpful comments. This research was sponsored by Oak Ridge National Laboratory, U.S. Department of Energy, under contract DE-AC05-84OR21400 with Martin Marietta Energy Systems, Inc.

\section{REFERENCES}

CH2M Hill, 1991, Results of Site Investigation, Phase I, KY/ER-4, CH2M Hill Southeast, Inc., Oak Ridge, TN.

Clausen, J.L, J.W. Douthitt, K.R. Davis and B.E. Phillips, 1992, Report of the Paducah Gaseous Diffusion Plant Groundwater Investigation Phase III, PGDP Report KY/E-150, 147 pp.

Davis, K.R., 1993, Cylinder Drop Test Area Characterization, PGDP informal memo (Aug. 20, 1993), $21 \mathrm{pp}$.

HRGI, 1993, Surface Geophysical Demonstration, Paducah Gaseous Diffusion Plant, Paducah, Kentucky, Technical Report, Hagar-Richter Geoscience, Inc., Salem, NH, 13 pp.

Olive, W.W., 1980, Geologic Map of the Jackson Purchase Region, Kentucky, U.S. Dept. Interior, U.S. Geological Survey, Map I-1217.

SSI, 1993, EKKO_Tools Users Guide, Version 1.1, Technical Manual 22, Sensors and Software, Inc., Mississauga, Ontario, $138 \mathrm{pp}$.

Yilmaz, O., 1987, Seismic Data Processing, Soc. Expl. Geophys., Tulsa, OK, 526 pp. 